\title{
A FEW REMARKS ON CZECH INTEREST LIMITATION RULES IN THE CONTEXT OF PANDEMIC
}

\begin{abstract}
This contribution focuses on an economic impact of the pandemic on Czech taxpayers in the context of the rule limiting deductibility of net financial expenses and thin capitalization rule. For this purpose, a hypothesis is proposed that these rules may in fact increase the negative economic impact of the pandemic.
\end{abstract}

Keywords: tax law, interest tax deductibility limitation, thin capitalization

\section{Introduction}

In the wake of the still ongoing pandemic of COVID-19, the governments over the globe have introduced number of fiscal measures [https://www.ey.com/en_gl/tax/howcovid-19-is-causing-governments-to-adopt-economic-stimulus (access 26.10.2020)] to mitigate the related economic impact. In the case of the Czech Republic, the International Monetary Fund estimates an annual decrease of GDP by 6.5\% [https://www.imf.org/en/ Countries/CZE\#countrydata, access 1.11.2020)] and the Czech Statistical Office reports decrease of GDP by $5.8 \%$ [https://www.czso.cz/csu/czso/ari/gdp-preliminary-estimate-3rd-quarter-of-2020, (access 01.11.2020)] for 2020.

It should be also considered that economic consequences of the pandemic caused recession are not evenly distributed even in a single economy, specific industries such as airline, travel or services have been brought by government measures to a practical standstill while other businesses merely experience material decrease of profitability.

In this context, the impact of laws which were in effect prior to the pandemic on taxpayers should be reviewed and it should be considered whether some of these rules would not in fact worsen negative economic impact of the pandemic.

Therefore, the goal of this contribution is to identify consequences of Czech interest tax deductibility rules 'sensu largo', i.e. rule limiting deductibility of net financial expenses and thin capitalization rule, in the light of imminent economic recession. It also provides practical insight into application of these rules and some elemental structuring employed by taxpayers to mitigate additional tax expenses. For this purpose, a hypothesis is proposed that these rules may in fact increase the negative economic impact of the pandemic recession.

This contribution uses such scientific methods as: description to introduce the respective rules, critical analysis to identify practical consequences of applicability of these rules in the current situation and synthesis to formulate the conclusions and thus meet the goal of the contribution. As the scope of this contribution is limited, only a few selected practical issues are discussed.

As regards the academic writing, the relevant authorities prevalently focus on compatibility of the interest limitation rules with the EU law or constitutional law principles such as ability to pay principle [Van Os 2016, pp. 193197; Dourado 2017, pp. 120-121; Hillmann, Hoehl 2018, pp. 23-24]. However, since the pandemic has affected the taxpayers only recently, none of the authorities focus specifically on related economic aspects. Therefore, the contribution also benefits from practical insight.

\section{Thin capitalization rule}

Since its adoption in 1993, the Czech Income Taxes Act included a thin capitalization rule which originally covered 
only interest on loans provided by Czech tax non-residents exceeding 4:1 equity to debt ratio, respectively 6:1 ratio in case of banking and insurance companies. This provision has been amended several times and currently disallows tax deductibility of interest (and associated expenses) on financial credit instruments provided by both Czech tax resident and non-resident related party creditor exceeding 4:1 equity to debt ratio or 6:1 ratio in case of banking and insurance companies. ${ }^{1}$

According to the unbinding guidance of the General Financial Directorate, the equity and amount of related party financial credit instruments is calculated on average basis for the respective tax period and in case of equity without the impact of current tax period's economic result [Guidance D-22 of the General Financial Directorate of 6 February 2015 no. 5606/15/7100-10].

In the light of the above, it seems that negative economic result achieved by a taxpayer due to pandemic in the current tax period should not immediately decrease the average equity and consequently should not increase the amount of tax non-deductible interest in the current tax period.

However, indirect economic effects of the pandemic should be considered as well. In the current tax period taxpayers may deplete their readily available financial resources which would have to be replenished to allow for payment of due liabilities and further economic activities. In case the additional financial resources were obtained by a financial credit instrument from a third party, the equity to related debt ratio would not be affected. However, it should be pointed out that such funding may be economically unreasonable due to taxpayer's potential credit rating deterioration caused by the negative economic result and structural changes of a balance sheet. The third-party creditor would in such situation probably require higher risk premium reflected in higher interest rate.

The related party creditor would be able to provide financial credit instrument at a lower than market price interest due to exception to arm's length principle provided by the sec. 23/7 of the Income Taxes Act, allowing lower interest rate between related parties if a creditor is Czech tax non-resident, Czech tax resident shareholder of the debtor or personal income taxpayer. It should be also considered that interest on financial credit instrument provided

1 The sec. 25/1/w of the Act. No. 589/1992 Coll. Income Taxes Act, as amended (further Income Taxes Act), also covers back-to-back financing flowing through a third-party intermediary. by taxpayer's Czech tax non-resident parent company may benefit from lower or nil withholding tax rate under applicable double tax treaty or Czech Transposition of Interest - Royalty Directive under sec. 19/1/zk) of the Income Taxes Act.

Although the related party financial credit instrument may be economically preferable, the equity to related debt ratio would decrease and interest from larger portion of related party debt might be tax non-deductible in the current tax period. However, this issue could be avoided by proportionate increase of equity to maintain optimal 4:1 equity to related debt ratio.

In the following tax period, the taxpayer's equity would be decreased by negative economic result of the current tax period which would decrease the equity to related debt ratio. Therefore, additional adjustments of the financial structure would be required to achieve optimal 4:1 ratio and preserve tax deductibility of entire amount of interest on related party debt ${ }^{2}$.

It should be pointed out that the above adjustments should be generally in the taxpayer's sphere of discretion since they may select a funding alternative according to their own needs and preferences [Ruling of Supreme Administrative Court ČR from 7 March 2007 no. 8 Afs $33 / 2005$ - 54]. Therefore, it could be reasonably argued that non-artificial adjustments of financial structure should be legitimate even in the light of 'abusus iuris' case law [Ruling of Supreme Administrative Court ČR from 15 October 2015 no. 9 Afs 57/2015 - 120].

\section{Rule limiting deductibility of net financial expenses}

In contrast to the thin capitalization rules, the rule limiting deductibility of net financial expenses has been introduced to the Czech tax law relatively recently by the Income Taxes Act amendment transposing the Anti-Tax Avoidance Directive (further ATAD).

In the tax periods starting on or after 1 April 2019, the rule limiting deductibility of net financial expenses is applicable next to the thin capitalization rules since the former rule targets only the otherwise tax-deductible financial expenses, i.e. not borrowing expenses non-deductible

\footnotetext{
2 From the practical perspective, these adjustments could be realized without undue administrative burden or costs via capitalization of the part of related party debt, e.g. in the form of contribution to other capital funds.
} 
under other provisions of the Income Taxes Act [Hrdlička 2018, pp.15-17].

The rule limiting deductibility of net financial expenses itself largely follows wording of the ATAD, i.e. exceeding borrowing costs are tax deductible up to CZK 80 million (which corresponds to approx. EUR 3 million) or, if higher, up to $30 \%$ of tax EBITDA (taxable profit before interest, taxes, depreciation and amortization). It should be pointed out this rule covers exceeding borrowing costs from both related and unrelated party debt.

The borrowing costs are relatively widely defined ${ }^{3}$ and include mainly expenses on loans, economically equivalent costs such as interest element of financial lease payments or notional interest amounts in derivative instruments, and other specified expenses such as exchange rate differences or capitalized interest. From these expenses should be deducted corresponding borrowing incomes [Kouba 2017, p. 16].

In line with the option provided by the ATAD, the Czech Republic introduced two subjective exclusions from the rule under sec. $23 \mathrm{f}$ of the Income Taxes Act, i.e. for listed financial undertakings and for independent taxpayers ${ }^{4}$ without a permanent establishment and obligation to consolidate financial statements.

Although the Income Taxes Act allows a carry forward of the excluded exceeding borrowing costs to unlimited subsequent periods, a carry back option provided by the ATAD has not been transpose. Furthermore, the carried forward excluded exceeding borrowing costs cannot be transferred to a legal successor under sec. $23 \mathrm{e} / 6$ of the Income Taxes Act.

Assuming the recession will have the impact on individual taxpayers suggested in the previous section, the amount of deductible interest under the rule limiting deductibility of net financial expenses would be significantly lower.

In case the taxpayers considerably increase amount of debt funding as is generally expected [https://www.

\footnotetext{
3 The term borrowing costs included in the ATAD arguably contains also expenses which are tax non-deductible under other provisions of ATAD, e.g. expenses on profit-linked loans which are excluded by sec. 25/1/zl of the Income Taxes Act.

4 Interestingly, the (non) independence status is here based on definition of associated enterprise for CFC purposes under sec. 38fa of the Income Taxes Act, i.e. entities related by equity, i.e. at least $25 \%$ direct or indirect participation in equity or voting rights, or at least $25 \%$ direct profit participation. In comparison, the thin capitalization rules affect also entities related personally or otherwise in the meaning of sec. 23/7 of the Income Taxes Act.
}

ey.com/en_uk/news/2020/11/covid-19-will-cause-firmsto-borrow-over-five-times-the-amount-in-2020-than-in2019-with-many-unlikely-to-start-repaying-until-2022, (access 26.10.2020)], the amount of interest would proportionately increase as well. At the same time the taxpayers' credit rating may deteriorate due to worse economic results or structural balance sheet changes, e.g. greater than optimal portion of debt funding, which may cause higher interest rate being demanded by creditors.

At the same time, it can be reasonably expected that taxpayers' EBITDA will significantly decrease and larger portion of the increased amount of net borrowing costs will be treated as tax non-deductible. In specific industries the taxpayers will not even be able to achieve positive EBITDA and the entire amount of borrowing costs would be tax non-deductible in the period under review.

Since the Czech Republic has not transposed carry back option, the taxpayers would be able to carry these non-deductible borrowing costs only to following tax periods. However, this capacity could be utilized in the future only if taxpayers would achieve EBITDA whose $30 \%$ would exceed the net borrowing costs in that tax period or would generate more interest income than expense. In addition, no such costs could be transferred to a surviving entity of a merger. Both of these aspects are relatively surprising as the Czech Republic has recently introduced carry back of tax losses and other tax attributes which can be generally transferred during a merger.

Similar observations have been formulated in relation to the practically identical German interest barrier rule by the German Federal Fiscal Court [2016] which stated that in practice a condition precedent to utilization of carried forward interest is a fundamental change of taxpayer's activities, i.e. either a comparative increase of interest income to expenses or a relatively significantly higher EBITDA [Lampert, Meickmann, Reinert 2016, pp. 59-60].

As in case of the thin capitalization rule, the taxpayers' economic decisions might be thus considerably distorted by the effects of the rule limiting deductibility of net financial expenses. Namely, in the case of taxpayers in recent financial distress, this performance-based rule would in practice decrease investment capacity by imposing additional tax cost on the deductible interest [Hillmann, Hoehl 2018, pp. 23-24]. From a practical view, the taxpayers may be by the rule forced to refinance to non-debt funding or shift investments from other financial instruments or projects to interest bearing debt instruments to 
decrease the net borrowing costs. These tax driven decisions would lead to economic inefficiencies.

Above economic consequences of the rule limiting deductibility of net financial expenses are in contrast with the general ability-to-pay principle, namely its net taxation aspect. An exemption to this principle should be justified by an overriding reason, in the case of German interest barrier rule such justification was, according to the government, a prevention of tax avoidance. Furthermore, in detailed analysis of this justification the German Federal Fiscal Court held that the tax avoidance is generally absent in purely domestic situations, third party funding situations, in the case of companies which were established recently, are in financial distress or operate in highly leveraged industries [Van Os 2016, pp. 193-197]. For these reasons the rule could not achieve its justifiable aim, was considered unconstitutional and the case was referred to Federal Constitutional Court which has not yet rendered its decision.

As the Czech rule limiting deductibility of net financial expenses is practically identical to the German interest barrier rule which served as an inspiration for the respective ATAD provision, it can be reasonably argued that the rule is inappropriate to attain its legitimate aim of tax avoidance prevention.

For the similar reasons it could be argued that the rule limiting deductibility of net financial expenses does not meet necessity, adequacy and proportionality requirements under the CJEU case law. It should be also noted that the rule does not give taxpayers a possibility to provide counterevidence of no tax avoidance. Therefore, it seems that the respective ATAD provision might have been drafted to formally comply with the EU non-discrimination principle and without due regard to its declared goal [Dourado 2017, pp. 120-121]. Instead the provision rather serves to safeguard a tax revenue of a respective state.

\section{Conclusion}

This contribution focused on the consequences of Czech thin capitalization rule and rule limiting deductibility of net financial expenses in the light of imminent economic recession. Based on the analysis of the respective provisions, it may be concluded that the recession driven financial effects such as the need of additional funding, deteriorated credit ratio or economic performance may increase the amount of tax non-deductible interest. Therefore, the hypothesis may be considered verified, the thin capitalization rule and the rule limiting deductibility of net financial expenses may accentuate the negative economic impact of the recession.

In addition, the taxpayers may attempt to structure around these rules to avoid the additional tax cost instead of making rational tax-non-driven decisions. This may bring about additional economic inefficiencies.

Therefore, it should be examined whether the interest-based tax base erosion cannot be prevented by less economically intrusive measures such as more thorough application of arm's length principle.

\section{Bibliography}

Country report on the Czech Republic. International Monetary Fund [online], https://www.imf.org/en/Countries/ CZE\#countrydata, access as of 1 November 2020.

COVID-19 will cause firms to borrow over five times the amount in 2020 than in 2019, with many unlikely to start repaying until 2022 [online], https://www.ey.com/ en_uk/news/2020/11/covid-19-will-cause-firms-to-borrow-over-five-times-the-amount-in-2020-than-in-2019with-many-unlikely-to-start-repaying-until-2022, access as of 26 October 2020.

Dourado A. (2017), The Interest Limitation Rule in the Anti-Tax Avoidance Directive (ATAD) and the Net Taxation Principle "EC Tax Review" vol. 26, issue 3.

EY Tax COVID-19 Response Tracker. Ernst \& Young. [online], https://www.ey.com/en_gl/tax/how-covid-19-iscausing-governments-to-adopt-economic-stimulus--, access as of 26 October 2020.

GDP Preliminary Estimate $-3^{\text {rd }}$ quarter of 2020. Czech Statistical Office [online], https://www.czso.cz/csu/czso/ari/ gdp-preliminary-estimate-3rd-quarter-of-2020, access as of 1 November 2020.

Hillmann L., Hoehl R. (2018), Interest Limitation Rules: At a Crossroads between National Sovereignty and Harmonization "European Taxation" vol. 58, issue 4.

Hrdlička L. (2018), Omezení uznatelnosti nadměrných výpi̊jčních výdajů $v$ daňovém baličku 2019 (Interest Limitation in Income Tax Law Amendment Proposal 2019, in Czech). Daně a právo v praxis. "Taxes and Law in Practice" vol. 23 , issue 4.

Kouba S. (2017), Smèrnice o vyhýbání se daňovým povinnostem (Anti-Tax Avoidance Directive, in Czech). "Financial, Tax and Accounting Bulletin” vol. 3, issue 4.

Lampert S., Meickmann T. and Reinert M. (2016), Article 4 of the EU Anti-Tax Avoidance Directive in Light of the 
Questionable Constitutionality of the German "Interest Barrier" Rule. "European Taxatio" no. 323.

Van Os P. (2016) Interest Limitation under the Adopted Anti-Tax Avoidance Directive and Proportionality. "EC Tax Review" vol. 25, issue 4.

\section{Legal acts}

Council Directive (EU) laying down rules against tax avoidance practices that directly affect the functioning of the internal market of 12 July 2016 (no.2016/1164, later amended).

Income Taxes Act of 18 December 1992 (Act. no. 589/1992 Coll., later amended).
Guidance D-22 of the General Financial Directorate from 6 February 2015 (no. 5606/15/7100-10).

Ruling of Supreme Administrative Court ČR from 7 March 2007 (no. 8 Afs 33/2005 - 54).

Ruling of Supreme Administrative Court ČR from 15 October 2015 (no. 9 Afs 57/2015 - 120).

\section{Author biography}

Jiř́i Kappel - Mgr. Ing. PhD candidate at Faculty of Law, Masaryk University and practicing tax lawyer at EY s.r.o. focusing on international, European and Czech tax law and frequently publishing both in domestic and foreign specialized journals. 